MACHINE BUILDING. PROCESS METALLURGY.

MATERIALS SCIENCE

МАШИНОБУДУВАННЯ. ТЕХНОЛОГІЯ МЕТАЛІВ.

МАТЕРІАЛОЗНАВСТВО

UDC 539.4

V.V. Pokrovsky, DEng, Prof.,

V.G. Sydiachenko, $\mathrm{PhD}$,

V.M. Ezhov, PhD, Senior Researcher

G.S. Pisarenko Institute for Problems of Strength of the National Academy of Sciences of Ukraine, 2 Timiryazevs'ka Str., 01014 Kyiv, Ukraine; e-mail: sidvg@mail.ru

\title{
FRACTURE RESISTANCE OF SHELL-STEEL REACTOR STEEL WITH MIXED DEFORMATION MODES FOR JUSTIFICATION OF EXTENSION OF NUCLEAR POWER PLANTS LIFETIME
}

В.В. Покровський, В.Г. Сидяченко, В.М. Сжсо. Тріщиностійкість корпусних реакторних сталей при змішаних модах деформування для обгрунтування продовження терміну експлуатації ядерних енергетичних установок. Попереднє термомеханічне навантаження сприяє підвищенню опору крихкому руйнуванню теплостійких сталей з тріщинами і є фундаментальною основою перспективного методу збільшення ресурсу для забезпечення безпечної експлуатації корпусів енергетичних реакторів. В існуючих нормах розрахунку на міцність обладнання атомних енергетичних установок розрахунок на тріщиностійкість здійснюється тільки для тріщин нормального відриву (мода I), але площина тріщини може мати довільну орієнтацію відносно зовнішніх зусиль. Мета: Метою роботи є експериментальне дослідження впливу попереднього термомеханічного навантаження за модами I і II на в’язкість руйнування за модами II і I реакторних сталей відповідно, а також попереднього термомеханічного навантаження за модою I + III на в'язкість руйнування по моді I + III. Mamepiaли i методи: Експериментальні дослідження статичної трішиностійкості виконували на зразках на чотириточковий згин (мода II), на циліндричних зразках на кручення (мода III) і на модифікованому компактному зразку з похиленою тріщиною (мода I+ III) для сталей марок $15 \mathrm{X} 2 \mathrm{HMФА(II)} \mathrm{i}$ 15X2МФА(II). Результати: Показано, що характеристики тріщиностійкості при поперечному і поздовжньому зсувах (моди II, III) менші, ніж при нормальному відриві (мода I) при температурі випробувань, вищій за температуру крихко-в'язкого переходу, i, навпаки, більші, коли температура випробувань нижча. Було встановлено, що попереднє термомеханічне навантаження за модою II викликає збільшення в'язкості руйнування за модою II і зниження в’язкості руйнування за модою I для окрихчених реакторних сталей. Цей самий показник у зазначених умовах практично не змінюється для пластичних реакторних сталей.

Ключові слова: тріщиностійкість, змішані моди руйнування, реакторні сталі, тріщиностійкість при поперечному зсуві.

V.V. Pokrovsky, V.G. Sydiachenko, V.N. Ezhov. Fracture resistance of shell-steel reactor steel with mixed deformation modes for justification of extension of nuclear power plants lifetime. Preliminary thermomechanical loading promotes increase of resistance to brittle fracture of heat-resistant steels with fractures and is the fundamental basis of the perspective method of increasing the resource for ensuring safe operation of power reactor corps. In existing standards for calculating the strength of equipment of nuclear power plants, the calculation for fracture toughness is performed only for plane opening mode of fracture (mode I), but the plane of the fracture can have an arbitrary orientation with respect to external forces. Aim: The aim of the research is an experimental study of the effect of the preliminary thermomechanical load under modes I and II on the fracture toughness for modes II and I of reactor steels, respectively, as well as the preliminary thermomechanical load under the I + III mode for the fracture toughness under the I + III mode. Materials and Methods: Experimental studies of static fracture resistance were performed on samples on four-point bending (mode II), on cylindrical specimens torsion (mode III), and on a modified compact sample with an oblique fracture (mode I + III) for 15Ch2NMFA(II) and 15Ch2MFA(II) steels. Results: It is shown that the fracture toughness characteristics for transverse and longitudinal displacements (modes II, III) are smaller than for normal detachment (mode I) at a test temperature exceeding the brittle-viscous transition temperature, and vice versa, more when the test temperature is lower. It was found that the preliminary thermomechanical load under mode II causes an increase in the fracture toughness under mode II and a reduction in the fracture toughness under mode I for tempering embrittlement reactor steels. Under these conditions, this index practically does not change for plastic reactor steels.

Keywords: fracture toughness, mixed fracture modes, reactor steels, fracture toughness at transverse shear.

Introduction. The preliminary thermomechanical loading contributes to increasing the resistance to brittle fracture of heat-resistant steels with fractures and is the fundamental basis of the long-term

DOI 10.15276/opu.1.51.2017.03

(C) 2017 The Authors. This is an open access article under the CC BY license (http://creativecommons.org/licenses/by/4.0/). 
method of increasing the resource for ensuring safe operation of the WWER reactors.

Experimental data on the effect of the preliminary thermomechanical load on the brittle strength of heat-resistant steels are limited to the investigation of fracture resistance by the normal detachment mechanism (mode I) [1...5].

Information on the effect of the preliminary thermomechanical load under various modes on the fracture toughness of steels with fractions is very limited and contradictory [6...10]. At the same time, in real constructions the orientation of the fracture plane with respect to the applied loads is arbitrary. Therefore, it is very important to take into account that the preliminary thermomechanical load, as well as the further operational load, leads to deformation of the elements with a fracture not only under mode I but in any mode, including mixed modes: I + II or I + III. In general, the available data for reactor vessel steels indicate that the preliminary thermomechanical load under mode I causes an increase in the fracture toughness at the lower shelf of the temperature dependence [1...6]. However, it is noted that the increase in the load of the component of the transverse shear (mode II) promotes the transition from brittle (shatter) to viscous (dimple) even under low temperatures (up to $-120^{\circ} \mathrm{C}$ ) [6]. In these cases, the preliminary thermomechanical load under modes I and II does not affect the fracture toughness of materials under transverse shear. When the preliminary thermomechanical load is carried out under mode II, the fracture toughness under mode I is reduced by $60 \%$ compared to the initial [6].

The authors of [7], as a result of the finite element analysis of the plate with an inclined fracture after the previous thermomechanical load at various load modes, confirmed the data obtained earlier in [6]. An exception was the case of a decrease in the fracture toughness under mode I after the preliminary thermomechanical load under mode II. According to calculations, there is an opposite trend, that is, an increase in the fracture toughness of materials is $190 \ldots 280 \%$, depending on the relative fracture length [7].

The aim of the research is an experimental study of the effect of the preliminary thermomechanical load under modes I and II on the fracture toughness for modes II and I of reactor steels, respectively, as well as the preliminary thermomechanical load under the I + III mode for the fracture toughness under the I + III mode.

Materials and Methods. Experimental studies were performed on heat-resistant hull steels of grades 15Ch2NMFA(II) and 15Ch2MFA(II) (Table 1).

Table 1

The mechanical properties of materials of the studied materials

\begin{tabular}{c|c|c|c}
\hline Material & $t,{ }^{\circ} \mathrm{C}$ & $\sigma_{0.2}, \mathrm{MPa}$ & $\sigma_{g}, \mathrm{MPa}$ \\
\hline \multirow{3}{*}{ 15Ch2MFA(II) } & 180 & 949 & 1129 \\
\cline { 2 - 4 } & 20 & 1014 & 1193 \\
\cline { 2 - 4 } & -150 & 1311 & 1486 \\
\hline \multirow{3}{*}{ 15Ch2NMFA(II) } & 180 & 590 & 668 \\
\cline { 2 - 4 } & 20 & 636 & 135 \\
\cline { 2 - 4 } & -150 & 970 & 1024 \\
\hline
\end{tabular}

To investigate the effect of the preliminary thermomechanical load for mixed modes I + II, a prismatic sample was used for asymmetric four-point or three-point bending.

Investigation of the characteristics of static fracture resistance at transverse shear, as well as investigation of the influence of the preliminary thermomechanical load on the characteristics of the fracture toughness of steels were performed on a Schenck servo-hydraulic test machine. A detailed procedure for carrying out the experiment, as well as the dependence for determining the stress intensity factor, are given in $[9,10]$. In the process of carrying out the experiment, the diagram "load displacement of active capture" was recorded. 
When calculating the critical values of the stress intensity factor, a load calculated from the $5 \%$ cut from the above diagram and the fracture length that corresponds to the fracture shear were used. The fracture length was refined with fractures of the samples after destruction.

Thus, in this paper, the fracture toughness implies the conditional value of the stress intensity factor corresponding to the fracture shear.

The longitudinal shear tests (mode III) were carried out on cylindrical samples with a pre-grown circumferential fracture on the BiSS Bi-00-701 unit, which allows simultaneous testing of the specimen for tension and torsion. To investigate the characteristics of fracture resistance at combined load under the

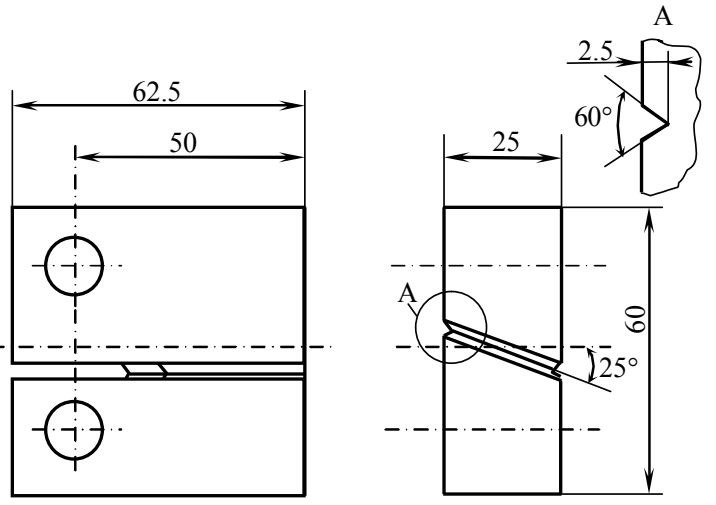

Fig. 1. Modified compact CT-1 sample with oblique fracture

I + III mode, the modernized compact sample used. It is shown in Fig. 1 [11].

To estimate the stress intensity factors (SIF) for loads under mode I and mode III ( $K_{\mathrm{I}}$ and $K_{\mathrm{III}}$, respectively), the recommendations of [11] were used.

The load $(F)$ applied to the sample can be decomposed into components:

$$
\begin{aligned}
& F_{\mathrm{I}}=F \cdot \sin \theta, \\
& F_{\text {III }}=F \cdot \cos \theta,
\end{aligned}
$$

where $\theta$ - the angle of the slit guides in the sample.

To account for the effect of the presence of guide slots in the specimen at an angle $\theta$, a correction is made for the net cross section of the sample:

$$
t_{\text {net }}=0.8 \cdot t / \sin \theta
$$

where $t$ - the thickness of the sample shown in Fig. 1 ( $t=25 \mathrm{~mm})$.

The values of $K_{\mathrm{I}}$ and $K_{\mathrm{III}}$ can be estimated using the decomposition of the applied load on the components $F_{\mathrm{I}}$ and $F_{\mathrm{III}}$ using formulas:

$$
\begin{gathered}
K_{I}=\frac{F_{I}}{0.8 \cdot t \sqrt{W}} \cdot f\left(\frac{a}{W}\right)(\sin \theta)^{2}, \\
K_{I I I}=\frac{F_{I I I}}{0.8 \cdot t \sqrt{W}} \cdot f\left(\frac{a}{W}\right)(\sin \theta \cos \theta),
\end{gathered}
$$

where $f\left(\frac{a}{W}\right)$ - calibration function that takes into account the load characteristics and the geometry of the sample; $(W=50 \mathrm{~mm})$.

$a$ - fracture length;

$W$ - distance from the line of application of force to the lateral surface of the sample in Fig. 1 all tests.

At the selected angle of the guide slots in the sample $\theta=25^{\circ}$ the ratio $K_{\mathrm{I}} / K_{\mathrm{III}}=2.14$ fulfilled for

Calculation of the equivalent stress intensity factor $\left(K_{e}\right)$ was carried out in accordance with the recommendations of work [12]:

$$
K_{e}=\sqrt{\frac{K_{\mathrm{I}}^{2}}{2}+\sqrt{\frac{K_{\mathrm{I}}^{4}}{4}+4 K_{\mathrm{III}}^{4}}}
$$


The preliminary thermomechanical load was carried out according to the scheme with full discharge, namely: the sample was heated to a temperature above the brittle-viscous transition - it was loaded to the level of $85 . . .90 \%$ of the fracture toughness value of the steel $K_{S}$ with the appropriate "load-cooling-destruction" mode. The following combinations of the effect of the preliminary thermomechanical load (PTL) on the fracture resistance were studied:

- PTL under mode I - destruction under mode II;

- PTL under mode II - destruction under mode I;

- PTL under mode II - destruction under mode II;

- PTL under mode I + III - destruction under mode I+III.

Results and Discussion.

The temperature dependences of the fracture toughness and the effect of the preliminary thermomechanical load under transverse shear (mode II).

The preliminary thermomechanical load affects the resistance to brittle fracture of heat-resistant steels under certain thermal power regimes. Therefore, in order to carry out experimental studies of the effect of the preliminary thermomechanical load on the strength characteristics of heat-resistant steels, it is necessary to know the values of their fracture toughness, and to establish the nature of destruction of these steels, depending on the test temperature. A fracture toughness test was carried out under mode II load. The obtained data were compared with the temperature dependence of the fracture toughness for the mode I load calculated in [13]. The patterns of change in fracture toughness testify to different characteristics of fracture resistance of reactor steels as a function of the test temperature (Fig. 2). The destruction of CT-1 samples (Fig. 1) from steel grade 15Ch2MFA(II) at a temperature of $20{ }^{\circ} \mathrm{C}$ is brittle, while the temperature of the viscous-brittle transition at the fracture toughness under mode I load $K_{\mathrm{IS}}=100 \mathrm{MPa}^{1 / 2}$ is $+50 \ldots+70{ }^{\circ} \mathrm{C}$, and for steel grade $15 \mathrm{Ch} 2 \mathrm{NMFA}$ (II) is $-50 \ldots-70{ }^{\circ} \mathrm{C}$.

Analysis of the destruction of the second mode of loading of 15Ch2MFA(II) steel shows brittle fracture at temperatures of $-150 \ldots-90{ }^{\circ} \mathrm{C}$, as evidenced by the brittle fracture nature of the fracture and the fracture propagation angle close to $70^{\circ}$ relative to the initial plane of the fracture when the specimen was finishing breaking. The obtained results correspond to the criterion of maximum normal stresses (generalized separation).

At the same time, at a test temperature of $-60{ }^{\circ} \mathrm{C}$ there was an insignificant viscous growth of the fracture in the plane of maximum shear strains that preceded brittle finishing breaking of the sample, and at a temperature of $20^{\circ} \mathrm{C}$ and higher, the fracture grew in the plane of maximum tangential deformations until destruction.

Analysis of the fractures of $15 \mathrm{Ch} 2 \mathrm{NMFA}$ (II) steel specimens, tested at transverse shear, shows that at all the investigated temperatures, fracture initiation was observed in the direction of maximum tangential deformations, and the angle of deviation from the original fracture plane was insignificant (about $5 \ldots 8^{\circ}$ ). In general, Fig. 2 shows that the transition to the mode II load leads to a decrease in the fracture toughness, determined from the fracture shifts at a temperature above the brittle-viscous transition temperature. When carrying out experimental studies it was established that when a load is applied to mixed modes of I+II or to pure mode II, an inhomogeneous stress field is produced at the fracture edge. By this, it is meant that one side of the fracture near its top is blunted, and tensile stresses predominate, and the other (opposite) shore becomes aggravated, and shear deformations prevail in this region. The predominance of one of these mechanisms depends on the coefficient of mixed loads, strain hardening, plastic properties and microstructure of the material. This ultimately determines the direction of further fracture development, as well as the magnitude of the fracture toughness characteristics in the case of a load under transverse shear. It should be noted the following regularities: for viscous materials, the fracture toughness with mixed modes decreases with the increase in the load of the landslide component (in mode II); for brittle materials, there is a reverse trend. Therefore, calculations on the fracture resistance of structural elements deforming in a mode different from the mode I, and made of plastic materials, based on fracture toughness characteristics obtained by a standard procedure, can lead to a non-conservative estimate. 
In general, the generalization of the experimental data and data from [14] shows that an increase in the yield strength leads to an increase of $K_{\mathrm{IIS}}$ in the fracture toughness under the mode II load and decrease of $K_{\mathrm{IS}}$. Thus, for steel grade $9 \mathrm{ChF}$, depending on heat treatment, an increase in the conventional yield strength $\sigma_{0.2}$ from 350 to $450 \mathrm{MPa}$ leads to a $16 \%$ increase in $K_{\text {IIS }}$ and a $33 \%$ decrease in $K_{\mathrm{IS}}$ (Fig. 3). Thus, the ratio of $K_{\mathrm{IS}} / K_{\mathrm{IIS}}$ decreases with increasing, which is also characteristic of the steels studied, especially in the temperature range $+50 \ldots+200{ }^{\circ} \mathrm{C}$.

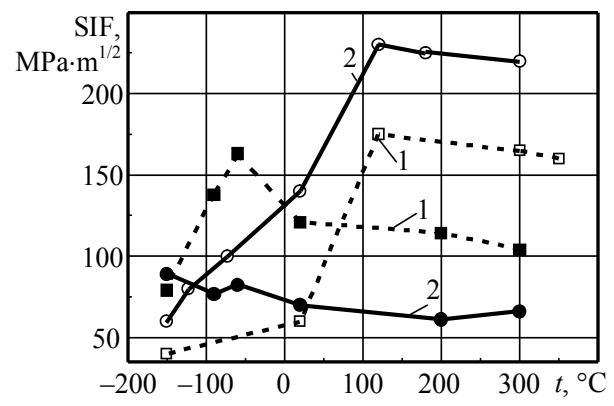

Fig. 2. Dependence of the fracture toughness of reactor steels under mode I (light points) and mode II (dark points) loads on the test temperature: 1 - 15Ch2MFA(II); 2 - 15Ch2NMFA(II)

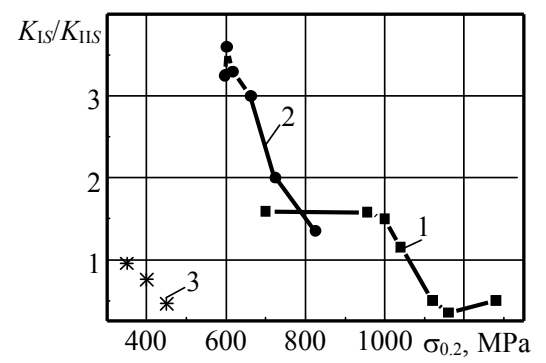

Fig. 3. Dependence of relative fracture viscosities under normal separation and transverse displacement on the relative yield strength: $1-15 C h 2 M F A(I I)$; 2-15Ch2NMFA(II); 3- 9ChF [14]

Thus, the ratio of the fracture toughness characteristics under normal separation and transverse shear in the general form can be represented as follows:

$$
\frac{K_{\mathrm{IS}}}{K_{\mathrm{IIS}}}=F\left(\sigma_{0.2}, n, \Psi, d\right),
$$

where $n$ - coefficient of strain hardening,

$\Psi$ - mixed modes coefficient,

$d$ - grain size of steel.

For the preliminary thermomechanical load, a temperature of $180{ }^{\circ} \mathrm{C}$ was chosen. This is because at this temperature the viscous fracture took place for viscous materials. The preliminary thermomechanical load was carried out to the level of $85 \%$ of the value of the corresponding critical value of the stress intensity factor for a given load and temperature. In Fig. 4 shows the data illustrating the effect of the preliminary thermomechanical load under mode II on the static fracture toughness obtained with a similar load.

From the data given, it can be seen that the previous thermomechanical load of the "full discharge" model for steel grade $15 \mathrm{Ch} 2 \mathrm{NMFA}(\mathrm{II})$ both at a temperature of $20^{\circ} \mathrm{C}$ and at $-150{ }^{\circ} \mathrm{C}$ does not affect the fracture toughness. And for steel grade $15 \mathrm{Ch} 2 \mathrm{MFA}(\mathrm{II})$ at a temperature of $-150{ }^{\circ} \mathrm{C}$ there is an increase in the fracture toughness by 1.8 times with respect to the value of $K_{\text {IIS }}$ at the value of the stress coefficient at the previous thermomechanical load $K_{\mathrm{PTL}}\left(K_{\mathrm{PTL}}=100 \mathrm{MPa} \times \mathrm{m}^{1 / 2}\right)$ (Fig. 4). Analysis of the experimental data for $15 \mathrm{Ch} 2 \mathrm{MFA}$ (II) steel, illustrating the effect of the preliminary thermomechanical load in mode II on the static fracture resistance for mode I, showed that after a preliminary thermomechanical load, the value of the critical stress intensity factor for fracture of the sample with fracture $K_{f}$ is only $24 \%$ and $64 \%$ of $K_{\mathrm{IS}}$ at temperatures of $-150{ }^{\circ} \mathrm{C}$ and $20^{\circ} \mathrm{C}$, respectively. At the same time, for the more plastic steel grade $15 \mathrm{Ch} 2 \mathrm{NMFA}(\mathrm{II})$, the preliminary thermomechanical load in mode II does not affect $K_{f}\left(K_{f}=K_{\mathrm{IS}}\right)$ (Fig. 4). 


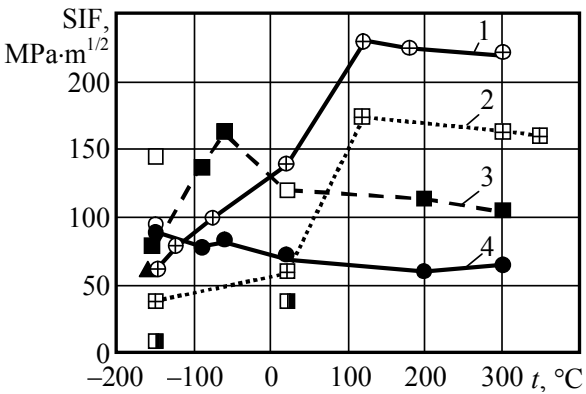

Fig. 4. Temperature dependence of the fracture toughness for various deformation schemes: 1, 2-mode I; 3, 4-mode II; O, $\square$-preliminary thermomechanical load according to mode II, destruction under mode II;

$\mathbf{\square}, \boldsymbol{\Delta}$-preliminary thermomechanical load according to mode II, destruction under mode I; 1, 4, O, $\mathbf{\Delta}$-indicators for steel of grade 15Ch2NMFA(II),

2, 3, $\square, \mathbf{\square}$-indicators for steel of grade $15 \mathrm{Ch} 2 \mathrm{MFA}(\mathrm{II})$

The difference in the fracture toughness characteristics of the steels studied after the preliminary thermomechanical load in mode II can be caused by the deformation features near the fracture top.

As noted above, with a transverse shear, one bank at the fracture top is dulled, and in this region the maximum hydrostatic stress is localized, and the equivalent plastic deformation is localized near the sharpened fracture bank $[15,16]$. The intensity of these processes can be different depending on the mechanical properties of the material. Therefore, in the case of a predominance of residual asymmetric blunting of one fracture edge because of the preliminary thermomechanical load, a region of tensile residual stresses is formed near the other shore, causes redistribution of stresses under repeated loading in mode I, and a decrease in the fracture toughness. If, under the preliminary thermomechanical load in mode II, the plastic deformation processes dominate in the fracture plane, this has little effect on the fracture toughness in mode I.

Temperature dependences of the fracture toughness and the effect of the preliminary thermomechanical load with longitudinal shear (mode III) and mixed mod I+ III load. Table 2 shows the values of fracture toughness characteristics with simultaneous loading in the I + III mode.

From the analysis of the obtained results, the next is following. As the test temperature decreases, the critical fracture toughness characteristics $\left(K_{I S}\right)$ obtained on standard compact samples is significantly reduced. They become approximately equal to the fracture toughness characteristics for the III $\left(K_{\text {IIIS }}\right)$ load at $-196{ }^{\circ} \mathrm{C}$, which are obtained by torsion of cylindrical samples with a radial fracture. The characteristic $\left(K_{\text {IIIS }}\right)$ increases somewhat with decreasing temperature. This behavior was noted for other materials [14].

Table 2

Characteristics of fracture resistance at a load under the $I+I I I$ mode at various temperatures

\begin{tabular}{c|c|c|c|c|c}
\hline$t,{ }^{\circ} \mathrm{C}$ & $K_{\mathrm{I}}, \mathrm{MPa} \mathrm{m}^{\mathrm{I} / 2}$ & $K_{\mathrm{III}}, \mathrm{MPa} \mathrm{m}^{\mathrm{I} / 2}$ & $K_{\mathrm{I}} / K_{\mathrm{IS}}$ & $K_{\mathrm{III}} / K_{\mathrm{IIIS}}$ & $P, \mathrm{H}$ \\
\hline+180 & 117 & 54 & 0.53 & 0.88 & 67300 \\
\hline-90 & 68 & 32 & 0.744 & 0.91 & 54000 \\
\hline-196 & 34.2 & 16 & 0.85 & 0.37 & 18700 \\
\hline-196 & 38.5 & 18 & 0.96 & 0.42 & 31500 \\
\hline
\end{tabular}

Fig. 5 shows that when the temperature is lowered, the fracture changes its development plane in accordance with the criterion of maximum normal stresses and is directed to destruction by normal separation both in pure shear (torsion of a cylindrical sample in Fig. 5, d) and under mixed load modes I+III (Fig. 5, $b$ ).

In Fig. 6 shows the dependence of the fracture toughness characteristics on the I and III models of steel grade $15 \mathrm{Ch} 2 \mathrm{NMFA}$ (II) on the test temperature, as well as the results of the $K_{e}$ calculations from formula (5) in the investigation of failure by mixed modes I+II after the preliminary thermomechanical load and without it.

Let note the increase in the coefficient $K_{e}$ as a result of the preliminary thermomechanical load for a modified compact sample by $75 \%$ at a temperature of $-196{ }^{\circ} \mathrm{C}$, at which the brittle fracture component is more pronounced for the material under study than at $-90{ }^{\circ} \mathrm{C}$, when the growth of $K_{e}$ was $33 \%$ with the same characteristic without a preliminary thermomechanical load. 


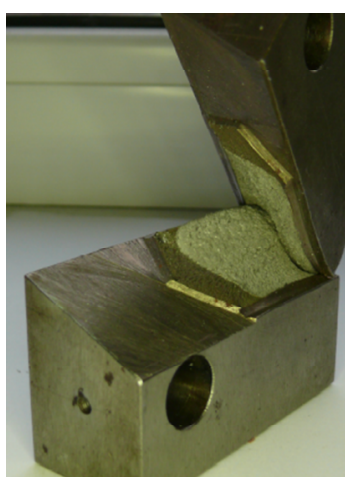

$a$

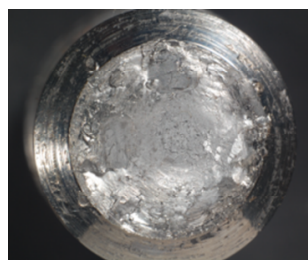

$c$
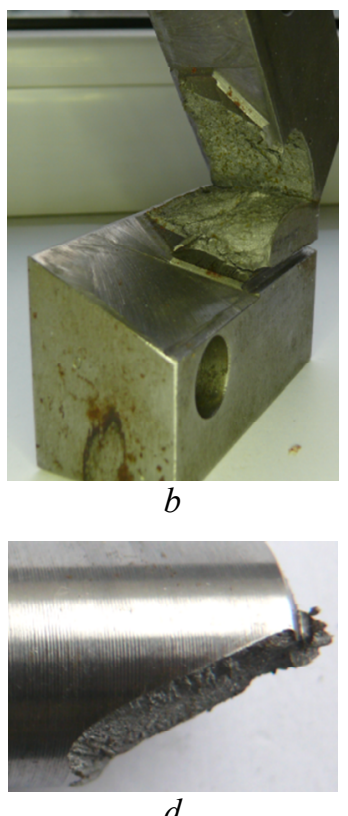

Fig. 5. Fractures of specimens:

$a, b$ - with an oblique incision modified compact; $c, d$-cylindrical. Test temperatures:

$180{ }^{\circ} \mathrm{C}(\mathrm{a}, \mathrm{c}),-90^{\circ} \mathrm{C}(\mathrm{b}),+196{ }^{\circ} \mathrm{C}(\mathrm{d})$

As is known from previous studies, the positive effect of the preliminary thermomechanical load, that is, the increase in the fracture toughness, is manifested to the greatest extent in brittle fracture. Therefore, in the case of normal separation, the preliminary thermomechanical load can increase the fracture toughness $\left(K_{\mathrm{IS}}\right)$ by two or more times, including for the material under investigation [2]. Therefore, as it follows from the data shown in Fig. 6, the longitudinal displacement component reduces the effect of the preliminary thermomechanical load on the brittle fracture toughness. Based on the results of experimental studies, it is possible to construct a diagram of the limiting state of bodies with fractures (Fig. 7). With mixed macro mechanisms of failure, the boundary conditions are reflected as follows:

$$
\frac{K_{\mathrm{I}}}{K_{\mathrm{IS}}}=f\left(\frac{K_{\mathrm{III}}}{K_{\mathrm{IIIS}}}\right) .
$$

To describe the surface of the limiting state, we can use the recommendations of the work [14]:

$$
\left(\frac{K_{I}}{K_{I S}}\right)^{2}+\left(\frac{K_{I I I}}{K_{I I I S}}\right)^{2}=1 \text {. }
$$

Analyzing the diagram in Fig. 7 it is possible to estimate the permissible value of the forces that can be applied to the structural elements.

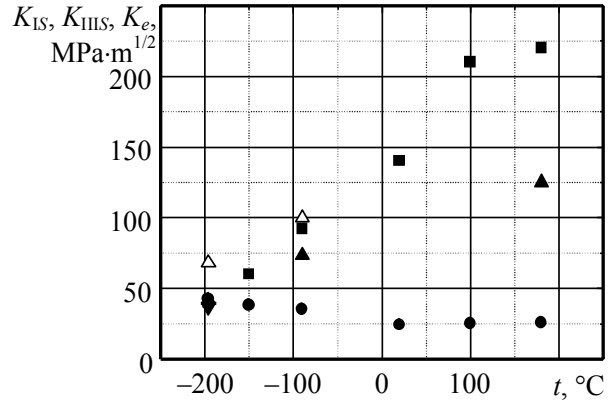

Fig. 6. Temperature dependence of fracture toughness: $\mathbf{D}_{\text {IS }}, \boldsymbol{\mathbf { 0 }}-K_{\text {IIIS }}, \boldsymbol{\Delta}-K_{e}$ (without preliminary thermomechanical load),

$\Delta-K_{e}$ (after preliminary thermomechanical load)

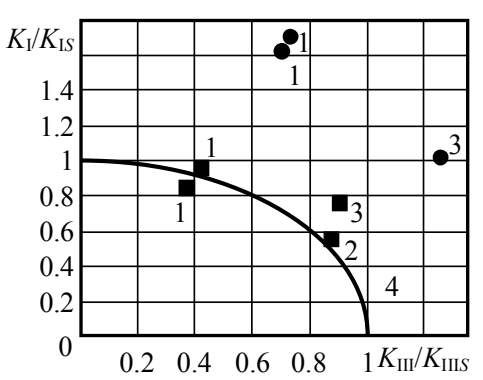

Fig. 7. The diagram of the limit state of steel grade 15Ch2NMFA(II) at different temperatures:

- without PTL, - - after PTL. Temperature: $1--196{ }^{\circ} \mathrm{C} ; 2-+180{ }^{\circ} \mathrm{C} ; 3--90^{\circ} \mathrm{C}$; 4 - calculation by formula (8)

Conclusions. Comparison of the critical values of stress intensity factors for normal separation, longitudinal and transverse displacements at temperatures below and above the temperature of the change in the character of fracture of steel from brittle to viscous shows the need for modification of normative documents for estimating the ultimate load-carrying capacity of structural elements with fractures, in particular, nuclear reactor vessels, the equipment of the $1^{\text {st }}$ and $2^{\text {nd }}$ circuits, pipelines, as well as gas and oil pipelines and other critical structures. 
As a result of a complex experimental investigation, it was shown that the fracture toughness characteristics for transverse and longitudinal displacements are smaller than at normal separation at the test temperature, and higher than the brittle-viscous transition temperature. Conversely, these values are greater when the test temperature is lower than the brittle-viscous transition temperature.

It was found that the preliminary thermomechanical load under mode II causes an increase in the fracture toughness under mode II and a reduction in the fracture toughness under mode I for tempering embrittlement reactor steels. For plastic steels, the fracture toughness does not change, which is due to the system of residual stresses that is asymmetric along the fracture edges.

The component of the longitudinal displacement reduces the fracture resistance, which was increased as a result of the preliminary thermomechanical load.

\section{Література}

1. The influence of plastic prestraining on brittle fracture resistance of metallic materials with cracks / V.V. Pokrovsky, V.T. Troshchenko, G.A. Kopcmsky, etc. // Fatigue \& Fracture of Engineering Materials \& Structures. - 1995. - Vol. 18, Issue 6. - PP. 731-746.

2. A promising method for enhancing resistance of pressure vessels to brittle fracture / V.V. Pokrovsky, V.T. Troshchenko, V.G. Kaplunenko, etc. // International Journal of Pressure Vessels and Piping. 1994. - Vol. 58, Issue 1. - PP. 9-24.

3. Timofeev, B.T. Calculated and experimental estimation of preliminary loading effect at elevated temperatures on fracture toughness of pressure vessel materials / B.T. Timofeev, V.I. Smirnov // International Journal of Pressure Vessels and Piping. - 1995. - Vol. 63, Issue 2. - PP. 135-140.

4. Chell, G.G. A theory of warm prestressing: Experimental validation and the implications for elastic plastic failure criteria // G.G. Chell, J.R. Haigh, V. Vitek // International Journal of Fracture. - 1981. Vol. 17, Issue 1. - PP. 61-81.

5. Smith, D.J. The effects of warm pre-stressing on cleavage fracture. Part 1: Evaluation of experiments / D.J. Smith, S. Hadidimoud, H. Fowler // Engineering Fracture Mechanics. - 2004. - Vol. 71, Issues 1314. - PP. 2015-2032.

6. Swankie, T.D. Low temperature mixed mode fracture of a pressure vessel steel subject to prior loading / T.D. Swankie, D.J. Smith // Engineering Fracture Mechanics. - 1998. - Vol. 61, Issues 3-4. - PP. 387-405.

7. Ayatollahi, M.R. Finite element analysis of a center crack specimen warm pre-stressed under different modes of loading / M.R. Ayatollahi, M. Mostafavi // Computational Materials Science. - 2007. Vol. 38, Issue 4. - PP. 847-856.

8. Покровский, В.В. Прогнозирование влияния предварительного термомеханического нагружения на вязкость разрушения корпусных теплоустойчивых сталей при смешанных схемах деформирования / В.В. Покровский, В.Г. Сидяченко // Міцність матеріалів та елементів конструкцій: тези доп. міжнар. наук.-техн. конф., Київ, Україна, 28-30 вересня 2010 р.: в 2 т. / відп. ред. В.Т. Трощенко; НАН України, Ін-т проблем міцності ім. Г.С. Писаренка. - К.: ІПМіц. ім. Г.С. Писаренка НАН України, 2010. - С. 340-348.

9. Исследование закономерностей развития трещин при смешанных модах нагружения / В.В. Покровский, В.Н. Ежов, В.Г. Сидяченко Ю.И. Коваль // Механічна втома металів: Праці 13го міжнародного колоквіуму (МВМ-2006), 25-28 вересня 2006 р., Тернопіль, Україна / відп. ред. В.Т. Трощенко. - Тернопіль: ТДТУ ім. І. Пулюя, 2006. - С. 259-265.

10. Сидяченко, В.Г. Методика исследования трещиностойкости реакторных сталей при смешанных I+II модах нагружения / В.Г. Сидяченко // Вісник НТУУ «КПІ». Серія: Машинобудування. 2011. - Вип. 63. - С. 83-86.

11. Manoharan, M. Combined mode I - mode III fracture toughness of a high carbon steel / M. Manoharan, J.P. Hirth, A.R. Rosenfield // Scripta Metallurgica. - 1989. - Vol. 23, Issue 5. - PP. $763-766$.

12. Шульженко, Н.Г. Задачи термопрочности, вибродиагностики и ресурса энергетических агрегатов: монография / Н.Г. Шульженко, П.П. Гонтаровский, Б.Ф. Зайцев. - Х.: ХНАДУ, 2011. - 444 с.

13. Pokrovskii, V.V. Influence of the modes of thermomechanical preloading on the resistance of heatresistant steels to brittle fracture / V.V. Pokrovskii, A.G. Ivanchenko // Strength of Materials. - 1999. Vol. 31, Issue 2. - PP. 200-209.

14. Panasyuk, V.V. Cyclic crack growth resistance of materials with mixed-mode macromechanisms of fracture / V.V. Panasyuk, Ya.L. Ivanytskyi, O.Ye. Andreykiv // Progress in Mechanical Behaviour of 
Materials: Proceedings of the $8^{\text {th }}$ International Conference on Mechanical Behaviour of Materials (ICM8), 16-21 May 1999, Victoria, Canada. - Victoria: University of Victoria, 1999. - V. 1. - PP. 398-403.

15. Laukkanen, A. Ductile elastic-plastic mixed mode I-II crack propagation mechanisms and fracture resistance in metallic materials / A. Laukkanen // Proceedings of the $12^{\text {th }}$ Bienniel Conference on Fracture, Fracture from Defects (ECF 12), 14-18 September 1998, Sheffield, UK. - West Midlands: Engineering Materials Advisory Services, 1998. - Vol. 2. - PP. 667-672.

16. Laukkanen, A. Evaluation of the effects of mixed mode I-II loading on elastic-plastic ductile fracture of metallic materials / A. Laukkanen, K. Wallin, R. Rintamaa // Mixed-Mode Crack Behavior. ASTM STP 1359 / ed. by K.J. Miller, D.L. McDowell. - West Conshohocken: ASTM, 1999. - PP. 3-20.

\section{References}

1. Pokrovsky, V.V., Troshchenko, V.T., Kopcmsky, G.A., Kaplunenko, V.G., Fiodorov, V.G., \& Dragunov, Yu.G. (1995). The influence of plastic prestraining on brittle fracture resistance of metallic materials with cracks. Fatigue \& Fracture of Engineering Materials \& Structures, 18(6), 731-746. DOI:10.1111/j.1460-2695.1995.tb00897.x

2. Pokrovsky, V.V., Troshchenko, V.T., Kaplunenko, V.G., Podkol'zin, V.Yu., Fiodorov, V.G., \& Dragunov, Yu.G. (1994). A promising method for enhancing resistance of pressure vessels to brittle fracture. International International Journal of Pressure Vessels and Piping, 58(1), 9-24. DOI:10.1016/0308-0161(94)90003-5

3. Timofeev, B.T., \& Smirnov, V.I. (1995). Calculated and experimental estimation of preliminary loading effect at elevated temperatures on fracture toughness of pressure vessel materials. International Journal of Pressure Vessels and Piping, 63(2), 135-140. DOI:10.1016/0308-0161(94)00028-H

4. Chell, G.G., Haigh, J.R., \& Vitek, V. (1981). A theory of warm prestressing: Experimental validation and the implications for elastic plastic failure criteria. International Journal of Fracture, 17(1), 61-81. DOI:10.1007/BF00043121

5. Smith, D.J., Hadidimoud, S., \& Fowler, H. (2004). The effects of warm pre-stressing on cleavage fracture. Part 1: evaluation of experiments. Engineering Fracture Mechanics, 71(13-14), 2015-2032. DOI:10.1016/j.engfracmech.2003.09.003

6. Swankie, T.D., \& Smith, D.J. (1998).Low temperature mixed mode fracture of a pressure vessel steel subject to prior loading. Engineering Fracture Mechanics, 61(3-4), 387-405. DOI:10.1016/S00137944(98)00065-4

7. Ayatollahi, M.R., \& Mostafavi, M. (2007). Finite element analysis of a center crack specimen warm pre-stressed under different modes of loading. Computational Materials Science, 38(4), 847-856. DOI:10.1016/j.commatsci.2006.06.001

8. Pokrovsky, V.V., \& Sydiachenko, V.G. (2010). Prediction of influence of warm prestressing on the fracture toughness of heat resistant steels under mixed mode deformation. In V.T. Troshchenko (Ed.), Proceedings of the International Scientific and Technical Conference on Strength of Materials and Structure Elements (pp. 340-348). Kyiv: IPS, NAS of Ukraine.

9. Pokrovsky, V.V., Yezhov, V.N., Sydiachenko, V.G., \& Koval, Yu.I. (2006). Investigation of crack growth behaviour under mixed mode loading. In V.T. Troshchenko (Ed.), Proceeding of the $13^{\text {th }}$ International Colloquium on Mechanical Fatigue of Metals (MFM-2006) (pp. 259-265). Ternopil: TSTU.

10. Sydiachenko, V.G. (2011). Methodology of research of fracture toughness of the pressure vessels steels at mixed I+II mode loading. Journal of Mechanical Engineering of the NTUU "KPI”, 63, 83-86.

11. Manoharan, M., Hirth, J.P., \& Rosenfield, A.R. (1989). Combined mode I - mode III fracture toughness of a high carbon steel. Scripta Metallurgica, 23(5), 763-766. DOI:10.1016/0036-9748(89)90527-9

12. Shulzhenko, N.G., Gontarovskiy, P.P., \& Zaitsev, B.F. (2011). The Problems of the Thermal Strength, Vibrodisgnostics and Resource of Power Machinery. Kharkiv: KhNAHU.

13. Pokrovskii, V.V., \& Ivanchenko, A.G. (1999). Influence of the modes of thermomechanical preloading on the resistance of heat-resistant steels to brittle fracture. Strength of Materials, 31(2), 200-209. DOI:10.1007/BF02511110

14. Panasyuk, V.V., Ivanytskyi, Ya.L., \& Andreykiv, O.Ye. (1999). Cyclic crack growth resistance of materials with mixed-mode macromechanisms of fracture. In F. Ellyin, J.W. Provan (Eds.), Progress in Mechanical Behaviour of Materials: Proceedings of the $8^{\text {th }}$ International Conference on Mechanical Behaviour of Materials (ICM8) (Vol. 1, pp. 398-403). Victoria: University of Victoria. 
15. Laukkanen, A. (1998). Ductile elastic-plastic mixed mode I-II crack propagation mechanisms and fracture resistance in metallic materials. In M.W. Brown, E.R de los Rios, K.J. Miller (Eds.), Proceedings of the $12^{\text {th }}$ Bienniel Conference on Fracture, Fracture from Defects (ECF 12) (Vol. II, pp. 667-672). West Midlands: Engineering Materials Advisory Services.

16. Laukkanen, A., Wallin, K., \& Rintamaa, R. (1999). Evaluation of the effects of mixed mode I-II loading on elastic-plastic ductile fracture of metallic materials. In K.J. Miller, D.L. McDowell (Eds.), Mixed-Mode Crack Behavior. ASTM STP 1359 (pp. 3-20). West Conshohocken: ASTM.

Received February 15, 2017

Accepted March 23, 2017 